\title{
Dispersions of carbon nanotubes in cholesteric liquid crystals: features of aggregate formation
}

\author{
L.N.Lisetski, S.S.Minenko, A.P.Fedoryako, \\ N.I.Lebovka", M.S.Soskin" \\ Institute for Scintillation Materials, STC "Institute for Single Crystals", \\ National Academy of Sciences of Ukraine, 60 Lenin Ave., 61001 Kharkiv, Ukraine \\ *F.Ovcharenko Institute of Biocolloidal Chemistry, National Academy of \\ Sciences of Ukraine, 42 Vernadsky Prosp., 03142 Kyiv, Ukraine \\ Institute of Physics, National Academy of Sciences of Ukraine, \\ 46 Nauky Pr., 03028 Kyiv, Ukraine
}

Received January 24, 2013

\begin{abstract}
For liquid crystal dispersions of carbon nanotubes (CNT), experimental data on time stability of their characteristics were obtained by three different methods (optical transmission vs. temperature, electric conductivity vs. time, and electric conductivity vs. voltage in conditions of Freedericksz transition). The results clearly suggest that induction of helical twisting in the nematic matrix substantially slows down the process of CNT aggregation, with cholesterol derivatives being more efficient as compared with non-steroid optically active dopants. This allows considering such dispersions as promising functional materials with enhanced time stability.
\end{abstract}

\begin{abstract}
Для жидкокристаллических дисперсий углеродных нанотрубок (УНТ) исследована стабильность их характеристик во времени тремя различными методами (зависимость оптического пропускания и электропроводности от времени, а также электропроводности от подаваемого напряжения в условиях перехода Фредерикса). Полученные результаты указывают на то, что индуцирование спирального закручивания в нематической матрице значительно замедляет процесс агрегации УНТ, причем производные холестерина оказываются более эффективными, чем нестероидные оптически активные допанты. Это позволяет рассматривать такие дисперсии как перспективные функциональные материалы с повышенной временной стабильностью.
\end{abstract}

\section{Introduction}

Dispersions of carbon nanotubes (CNT) in liquid crystalline (LC) media have rapidly developed into a new class of composite materials with broad prospects of their practical application [1-4]. Properties of CNT dispersions in nematic LC have been extensively studied in many works (see, e.g., [5-11] and references therein). In such systems, arrays of initial CNT bundles are easily decomposed, e.g., by ultrasonication, with formation of a rather homogeneous LC structure with individual CNTs aligned along the nematic director and incorporated into the general orientational ordering. The main problem is rather low time stability of such systems, which is related to the tendency of CNTs to form aggregates of fractal nature $[7,10]$. Numerous ways have been proposed for suppressing or hindering the aggregation process, which include chemical functionalization of CNTs, addition of simple surfactants or specially designed amphiphilic compounds to the dispersion, application of the electric field, etc. ([12-15] and references therein).

Much less attention was paid to CNT dispersions in cholesteric liquid crystals (CLC). 
It is still possible to give a presumably complete list of such publications [16-21], starting with a preliminary attempt where authors themselves acknowledge poor homogeneity of the obtained dispersions [16] or a study on dielectric properties of CNT dispersions in a nematic with a chiral dopant, with no reference to peculiar CLC properties [17]. Effects of CNT on mesomorphic transition temperatures and viscosity of cholesterol esters were reported in [18], while in [19] chiral nematics with dispersed CNTs were used as sensor materials for vapor detection. In our previous studies, we observed that CLC+CNT dispersions showed optical transmission vs. temperature behavior rather similar to their nematic counterparts, CNT effects on selective reflection spectra were rather weak, and it was argued that CNTs were probably aligned in the planes of quasinematic layers [20]. Our further studies [21] suggested that CNT aggregate formation could be much slower in the cholesteric phase as compared with nematics. Thus, one of the aims of this work was to study the effects of helical twisting on time stability of nematic and cholesteric CNT dispersions. Another aspect was to check the applicability of the stabilized CLC+CNT systems for effects based on Freedericksz-type transitions.

\section{Materials and methods}

Three types of cholesteric LC systems were used - mixtures of cholesterol derivatives (steroid cholesterics), mixtures of nematic LC with cholesterol derivatives (nematic-cholesteric mixtures), and nematics doped with chiral additives (induced cholesterics). As a nematic component, we used a standard nematic LC 4-pentyl-4'-cyanobiphenyl (5CB). Two mixtures of cholesterol derivatives were used: a mixture of $80 \%$ COC (cholesteryl oleyl carbonate, Aldrich, USA) and $20 \%$ CC (cholesteryl chloride, Chemical Reagents Plant, Kharkiv, Ukraine), hereafter referred to as COC/CC, and a mixture of $65 \%$ cholesteryl nonanoate, $30 \%$ cholesteryl formate and $5 \%$ cholesteryl butyrate (Chemical Reagents Plant, Kharkiv, Ukraine), designated below as M5. The chiral dopant used was octane- 2 - yl - 4 - ( ( 4 - (hexyloxy) benzoyl) oxy)benzoate (R-811, Merck, Germany).

The multi-walled carbon nanotubes (CNT) of diameter $d \sim 10 \mathrm{~nm}$ and length $l \sim 5-$ $10 \mu \mathrm{m}$ were obtained from Arry, Germany. The CLC + CNT dispersions were obtained by adding the appropriate weights of the dis- persed substance to CLC solvent in the isotropic state with subsequent 20-30 min sonication of the mixture using a UZDN-2T ultrasonic disperser, in accordance with procedure essentially similar to the previously described $[5,6,20]$.

The optical transmission spectra were measured in a $50 \mu \mathrm{m}$ thick cell using a $\mathrm{Hi}$ tachi 330 spectrophotometer. The studied dispersion was introduced between the cell walls by the capillary forces at a temperature above the cholesteric-isotropic transition point. Before introduction of the CNTs+LC composites into the cell, the cell walls were treated with polyvinyl alcohol water solution and, after drying, rubbed in one direction to obtain the planar texture. All optical transmission values were determined at $700 \mathrm{~nm}$. This wavelength was chosen as optimal because it was well above the absorption region and selective reflection bands of the studied CLC solvents.

The home-made cell, used for measurement of electrophysical characteristics, included a grounded guard ring, which reduced the influence of the edge effects. The cell was a capacitor with metal plates, covered by a polyvinyl alcohol film rubbed in one direction for ensuring the planar texture. The cell thickness $(50 \mu \mathrm{m})$ was set by a Teflon spacer. Before the measurements, the cell parts were washed in hexane and dried at $390 \mathrm{~K}$. After assembling, the cell was connected to E7-12 LCR-meter (KALIBR, Belarus), making sure that $\operatorname{tg} \delta$ of the empty cell did not exceed 0.0001 .

For conductivity measurements, the a.c. voltage of $0.25 \mathrm{~V}$ and $1 \mathrm{MHz}$ was used, which should not affect the LC director field. The experimental set-up provided application of d.c. bias voltage up to $40 \mathrm{~V}$ to the cell. The external D.C. voltage could align the molecules, thus leading to re-orientation of the nematic director and corresponding changes in conductivity.

In all the experiments, characteristics of the LC+CNT dispersions were first measured just after preparation (sonication), and then measurements under the same conditions were repeated after incubation of these dispersions for several hours, i.e., when the formation process of CNT aggregates was expected to be sufficiently developed (at least partially completed).

\section{Results and discussion}

Typical results on optical transmission as function of temperature for dispersions of 


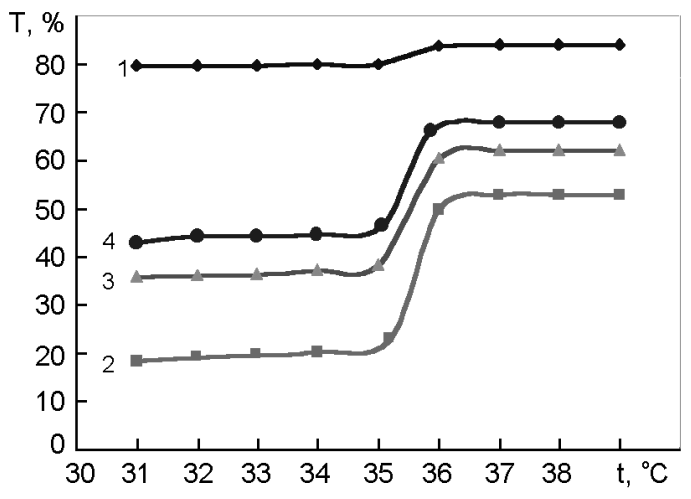

a)

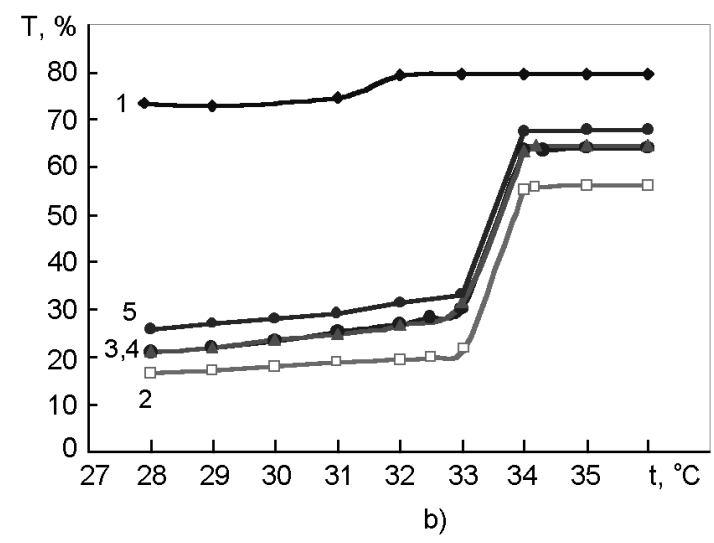

b)

Fig. 1. Optical transmission vs. temperature for dispersions of $0.1 \%$ CNT in liquid crystal matrices - nematic 5CB (a) and cholesteric 5CB + $5 \%$ M5 (b): pure LC matrix (1), LC matrix with

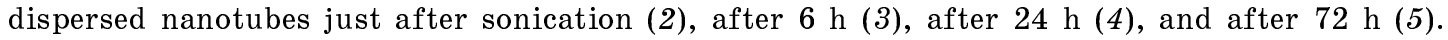

CNT in the liquid crystal matrices used are shown in Fig. 1.

For 5CB matrix (Fig. 1a), the observed behavior is similar to that observed for other nematic matrices $[5,6]$. The introduction of CNTs leads to substantial lowering of the transmittance level and to much larger "transmission jump" at the nematic to isotropic phase transition. After incubation of the initial dispersion at room temperature, transmission values increase, and the jump becomes smaller, indicating formation of CNT aggregates.

For the cholesteric matrix (where helical twisting is induced by addition of the cholesteric component), the picture is noticeably different (Fig. 1b). In this case, changes in optical transmission are much weaker, and the transmission jump value remains practically the same even after rather long incubation. This suggests that CNT aggregation processes in such system are much less intense, and, accordingly, time stability of the CLC + CNT dispersion can be expected to be much higher as compared with similar materials based on 5CB without cholesteric additives.

The next step in our studies of the effects of LC matrix composition upon CNT aggregation processes was the use of electrophysical methods, in particular, measurements of electric conductivity. As it was shown earlier [7, 8], formation of CNT during incubation of LC dispersions is manifested in lowering of the relative conductivity. The results obtained are shown in Fig. 2.

For CNT dispersion in 5CB (curve 1), the decrease in conductivity is very fast - already after $1-2 \mathrm{~h}$ the conductivity falls by

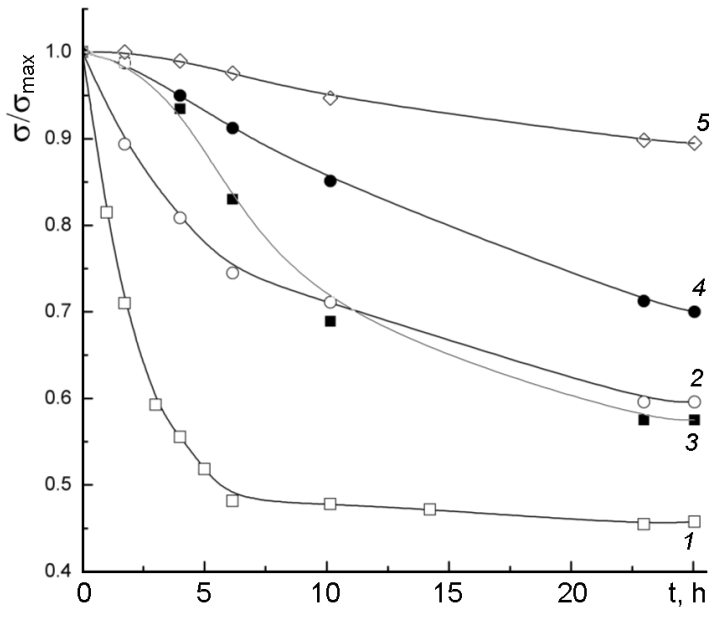

Fig. 2. Variation of relative conductivity with time (decreasing with respect to the initial value) during incubation of CNT dispersions $(0.1 \%)$ in different liquid crystal matrices: $1-5 \mathrm{CB}, 2-5 \mathrm{CB}+5 \% \mathrm{R}-811,3-$ $5 \mathrm{CB}+5 \% \mathrm{COC} / \mathrm{CC}(80: 20 \%), 4-5 \mathrm{CB}+$ $30 \% \mathrm{COC} / \mathrm{CC}, 5-$ cholesteric mixture $\mathrm{COC} / \mathrm{CC}(80: 20 \%)$.

$\sim 30 \%$ with respect to its initial value, and after $\sim 5$ hours the aggregation process appears to be essentially completed. This is in a good agreement with time characteristics of optical transmission changes (Fig. 1a). Introduction of chiral dopant R-811 into the nematic matrix makes the aggregation process much slower (curve 2). This effect is even more pronounced when COC/CC mixture is used as cholesteric additive - the decrease in conductivity by $\sim 10-15 \%$ requires 5 times longer incubation as compared with 5CB matrix (curve 3). Further increase in the concentration of the 


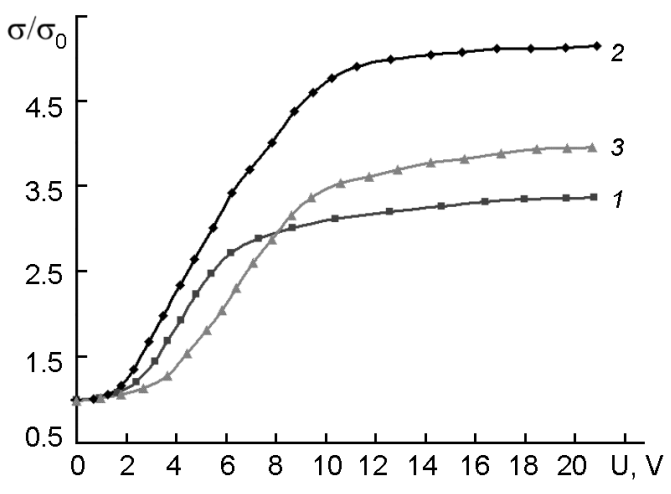

a)

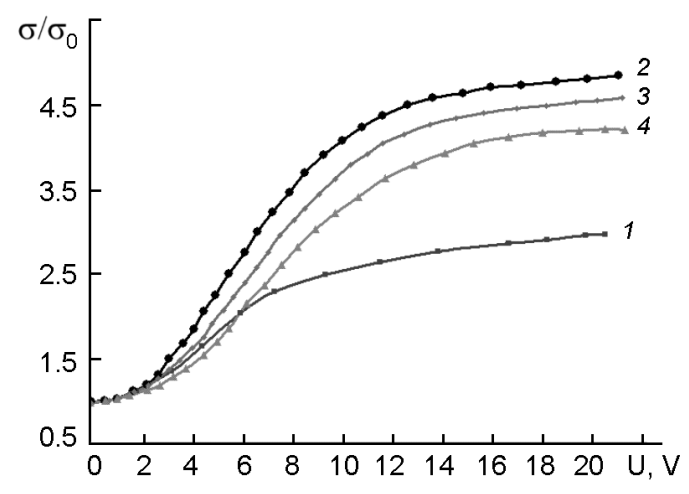

b)

Fig. 3. Relative increase in conductivity vs. applied voltage for dispersions of $0.1 \%$ CNT in liquid crystal matrices - nematic 5CB (a) and cholesteric 5CB + $5 \%$ M5 (b): pure LC matrix (1), LC matrix with dispersed nanotubes just after sonication (2), after $6 \mathrm{~h}(3)$, and after $24 \mathrm{~h}(4)$.

cholesteric component (i.e., stronger helical twisting) results in even slower CNT aggregation, ensuring higher time stability of the material (curve 4). Lastly, when we use a mixture of cholesterol derivatives without nematic components, the LC+CNT dispersion becomes even more stable (curve 5), with CNT aggregation processes largely suppressed. It should be noted that in this case practically no signs of aggregation could be observed by optical microscopy.

In the next set of experiments, we studied changes in relative conductivity under application of electric field in the conditions of Freedericksz transition. As in the case of nematic matrices, reorientation of the liquid crystal with dispersed CNT was induced by d.c. voltage applied to the LC cell, while conductivity measurements were carried out using weak a.c. voltage [5, 7, 22]. The results obtained are shown in Fig. 3.

In CB-based samples (Fig. 3a) joint alignment of LC molecules and nanotubes along the electric field direction resulted in the strongly increased conductivity, since at voltages above the Freedericksz transition from planar to homeotropic orientation a large contribution came from charge transfer along the highly conductive CNTs. The presence of dispersed nanotubes also led to lowering of the threshold voltage (curve 2 as compared with curve 1). Due to subsequent aggregation processes, orientation of CNTs along the field direction became less efficient (it is easy to understand assuming that reorientation of an aggregate requires stronger action of external factors as compared to reorientation of individual nanotubes not connected to each other). Correspondinly, the electric conductivity is in- creased to lesser extent, and the required threshold voltage increases (curve 3).

When the LC matrix is $5 \mathrm{CB}+5 \% \mathrm{M} 5$ (Fig. 3b), the threshold voltage without nanotubes is somewhat higher, and the conductivity rise is somewhat lower than with pure 5CB (evidently due to smaller dielectric anisotropy of the LC matrix). After introduction of CNTs (curve 2), just after sonication the observed behavior is generally similar to the corresponding case in Fig. 3a. However, as distinct from 5CBbased dispersion, the effects of incubation are much weaker because CNT aggregation goes much less intensively (curves 3,4 ).

\section{Conclusions}

Thus, the above evidence obtained by three different methods clearly shows that introduction of cholesteric additives to the nematic matrix substantially suppresses (or at least slows down) formation of CNT aggregates in liquid crystal dispersions.

This can be explained on the basis of our earlier assumption [20] that CNTs dispersed in helically twisted orientationally ordered media tend to be located in the planes of quasi-nematic layers. This imposes additional restrictions on mutual orientation of adjacent nanotubes, hindering them from taking up relative positions suitable for aggregation [10]. In addition, cholesterol esters can play the role of amphiphilic molecules as described in [13], interacting with CNTs and LC molecules by their steroid and alkyl moieties.

\section{References}

1. J.P.F.Lagerwall, G.Scalia, J.Mater.Chem., 18, 2890 (2008). 
2. M.Rahman, W.Lee, J.Phys.D:Appl.Phys., 42, 063001 (2009).

3. L.Dolgov, O.Kovalchuk, N.Lebovka, S.Tomylko, O.Yaroshchuk, in: Carbon Nanotubes, ed. by J.M.Marulanda, InTech Education and Publishing, Vukovar, Croatia (2010), p.451.

4. Y.A.Garbovskiy, A.V.Glushchenko, Solid State Phys., 62, 1 (2011).

5. L.N.Lisetski, S.S.Minenko, A.P.Fedoryako, N.I.Lebovka, Physica E, 41, 431 (2009).

6. A.I.Goncharuk, N.I.Lebovka, L.N.Lisetski, S.S.Minenko, J.Phys. D:Appl.Phys., 42, 165411 (2009).

7. S.S.Minenko, L.N.Lisetski, A.I.Goncharuk, N.I.Lebovka, V.V.Ponevchinsky, M.S.Soskin, Functional Materials, 17, 454 (2010).

8. L.N.Lisetski, S.S.Minenko, V.V.Ponevchinsky, V.V.Ponevchinsky, M.S.Soskin, A.I.Goncharuk, N.I.Lebovka, Mat. Sci. Eng. Technol., 42, 5 (2011).

9. L.N.Lisetski, A.M.Chepikov, S.S.Minenko, N.I.Lebovka, M.S.Soskin, Functional Materials, 18, 148 (2011).

10. L.N.Lisetski, N.I.Lebovka, S.V.Naydenov, M.S.Soskin, J. Mol. Liq., 164, 143 (2011).

11. V.V.Ponevchinski, A.I.Goncharuk, S.S.Minenko, L.N.Lisetski, N.I.Lebovka Nonlin. Opt. and Quant. Opt., 43, 281 (2012).
12. S.Schymura, M.Kuhnast, V.Lutz et al., Adv. Funct. Mat., 20, 3350 (2010).

13. M.Kuhnast, C.Tschierske, J.Lagerwall, Chem. Commun., 46, 6989 (2010).

14. Y.Li, Y.Y.Huang, E.M.Terentjev, Langmuir, 27, 13254 (2011).

15. W.Tie, G.H.Yang, S.S.Bhattacharyya et al., $J$. Phys. Chem. C, 115, 21652 (2011).

16. S.Schymura, J.Lagerwall, in: 37. Arbeitstagung Flussigkristalle, Stuttgart (2009), p.33.

17. O.Koysal, Synth. Metals, 160, 1097 (2010).

18. M.V.Yakemseva, I.V.Novikov, N.V.Usol'tseva, in: Zhidkie Kristally i ikh Prakticheskoe Ispol'zovanie, Ivanovo, Russia, 4, 98 (2010) [in Russian].

19. C.-K.Chang, S.-W.Chiu, H.-L.Kuo et al., Appl. Phys. Lett., 100, 043501 (2012).

20. L.N.Lisetski, S.S.Minenko, A.V.Zhukov et al., Mol. Cryst. Liq. Cryst., 510, 43 (2009).

21. A.M.Chepikov, S.S.Minenko, L.N.Lisetski, N.I.Lebovka, N.V.Usol'tseva, M.S.Soskin Functional Materials, 19, 343 (2012).

22. S.S.Minenko, A.I.Kocherzhyn, L.N.Lisetski, N.I.Lebovka, Functional Materials, 16, 319 (2009).

\title{
Дисперсії вуглецевих нанотрубок у холестеричних рідких кристалах: особливості формування агрегатів
}

\author{
Л.М.Лисещький, С.С.Міненко, О.П.Федоряко, \\ М.І.Лебовка, М.С.Соскін
}

Для рідкокристалічних дисперсій вуглецевих нанотрубок (ВНТ) досліджено стабільність їх характеристик у часі трьома різними методами (залежності оптичного пропускання та електропровідності від часу, а також електропровідності від прикладеної напруги в умовах переходу Фредерікса). Отримані результати вказують на те, що індукція спірального закручування у нематичній матриці значно уповільнюе процес агрегації ВНТ, причому похідні холестерину діють більш ефективно, ніж нестероїдні оптично активні допанти. Це дозволяє розглядати такі дисперсії як перспективні функціональні матеріали з підвищеною часовою стабільністю. 